\title{
Japan's science agency seeks extra billions, despite recession
}

[TOKYO] Japan's Science and Technology Agency is planning a dramatic increase in its budget for brain science and genomics next fiscal year. The agency's budget request for 1999 submitted on Monday this week (31 August) also includes new funds for a deepsea drilling ship that is intended to play a key role in the extension of the international Ocean Drilling Programme.

Despite Japan's economic woes, the government continues to plough new money into science and technology. The Science and Technology Agency is asking for an increase of only 2.9 per cent in its standard budget for fiscal year 1999, which starts in April next year. But it is also requesting an extra $¥ 17.8$ billion (US\$123 million), equivalent to an additional 2.3 per cent, under a special appropriation to develop infrastructure for telecommunications, science and technology, and the environment for the next century.

This special one-off appropriation, which is available for all science-related ministries and agencies in 1999 and is expected to total $¥ 150$ billion, is intended to help Japan establish a sounder economic base. The agency's request may be cut back before approval by the Cabinet and Ministry of Finance at the end of the year, but such adjustments are usually minor.

The agency is requesting $¥ 9.1$ billion — $¥ 6.8$ billion more than this year — to bring together the life sciences and information sciences in a broad new area of research that encompasses bioinformatics but also covers elucidation of such things as information processing in the brain. Some $¥ 6.4$ billion will come from the special appropriation for this programme.

Partly because of this appropriation, the budget for genome science is increased 66 per cent to $¥ 11.6$ billion, including $¥ 7.7$ billion for a new genomic science centre to be established by the Institute of Physical and Chemical Research (RIKEN) in Yokohama (see Nature 392, 219; 1998). Some ¥3.3 billion of the total will come from the special appropriation.

The centre will open a temporary office in October at RIKEN's main campus in Wako city until its new building is completed in Yokohama in 2000. It will focus on three areas of research: cDNA sequencing and investigation of genome function for both humans and mice; development of a 'gene encyclopedia' of the mouse genome; and an NMR park for investigating protein function and structure.

Similarly, the budget for brain science is increased 36 per cent to $¥ 19$ billion, includ-

\begin{tabular}{|c|c|c|}
\hline \multicolumn{3}{|c|}{$\begin{array}{l}\text { Highlights of Japan's Science and Technology } \\
\text { Agency budget request for fiscal year } 1999\end{array}$} \\
\hline & $\begin{array}{l}\text { Request } \\
\text { ( } ¥ \text { billion) }\end{array}$ & $\begin{array}{c}\text { Change since } \\
1998(\%)\end{array}$ \\
\hline Total budget & $761.8^{*}$ & +2.9 \\
\hline $\begin{array}{l}\text { Special appropriation } \\
\text { for } 21 \text { st century }\end{array}$ & 17.8 & - \\
\hline $\begin{array}{l}\text { Life/information } \\
\text { sciences }\end{array}$ & 9.1 & +386 \\
\hline Genome science & 11.6 & +66 \\
\hline Brain research & 19.0 & +36 \\
\hline Deep-sea drilling ship & 5.7 & +946 \\
\hline
\end{tabular}

ing $¥ 11.7$ billion for the new Brain Science Institute at RIKEN's main campus. The increased budget also includes $¥ 3$ billion of the new money for life and information sciences.

Other beneficiaries of the special appropriation will be the world's marine geologists. The agency is requesting $¥ 5.7$ billion for a deep-sea drilling ship expected to be completed in 2003. Researchers at the Japan Marine Science and Technology Center, who are leading the programme, are confident of getting a total budget of US\$120 million for the ship's design and construction over the next three years.

The ship will have 'riser technology' adapted from the petroleum industry and will allow drilling to much greater depths in the Earth's crust and in more difficult geological terrain. The ship is intended to play a key role in the future of the Ocean Drilling Programme beyond 2003, when the current phase of the programme ends (see Nature 388, 409; 1997 \& 394, 820; 1998).

The agency's budget also gives the first signs of the pending merger of the agency with the Ministry of Education, Science, Sports and Culture (see Nature 390, 327; 1997). The ministry and agency are making joint requests for some projects, for example, to fund research on the Moon by both the National Space Development Agency, affiliated to the agency, and the Institute of Space and Astronautical Science under the education ministry.

DavidSwinbanks

\section{Peregrine leads flight from endangered list}

[WASHINGTON] The US interior department last week proposed removing the peregrine falcon from its list of endangered species. This would be the first time in three years that a species has been 'delisted' because of a dramatic recovery in numbers.

The peregrine is the first of about two dozen species scheduled to be taken off the list in the next two years, following a directive in May by interior secretary Bruce Babbitt to expedite delistings.

More than 1,100 animals and plants are protected under the Endangered Species Act (ESA). But only 27 species, subspecies or populations have been taken off the list since the act came into force in 1973.

John Fay, a biologist at the endangered species division of the US Fish and Wildlife Service, says: "We're pretty conservative about calling something recovered." Because some endangered populations had been declining for as long as a century before the ESA was enacted, he says, "after 25 years it's unreasonable to expect a lot of recoveries".

The service has lacked the resources to devote to delisting, having only recently recovered from a congressional moratorium on new listings in 1995 that created a backlog of species in need of protection.

The peregrine has bounced back from a low of 324 nesting pairs in 1975 to at least 1,593 breeding pairs in the United States and

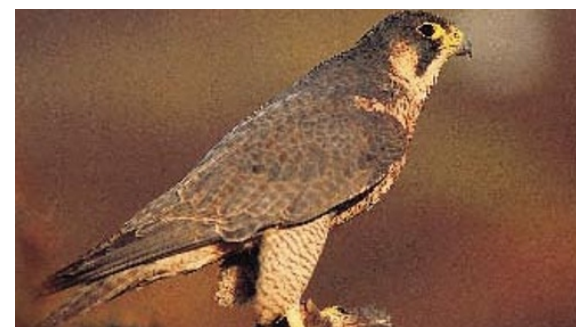

Out of danger: US peregrines stage a comeback.

Canada. The comeback is due more to the banning of the pesticide DDT in the 1970s and to an aggressive captive breeding programme than to ESA protection. This has led congressional critics to attack Babbitt for touting the peregrine and other delisting candidates as ESA success stories.

Last month, 30 members of the Western Caucus, a conservative group of property rights advocates in the House of Representatives, wrote to Babbitt challenging his statement in May that the ESA has been proved a success. Some species are being removed from the list, they point out, only because they have become extinct or have been reclassified, and others are being delisted because their population estimates have grown as scientists discover more of them in the wild. Most biologists and wildlife managers support delisting in principle, but urge caution. Tony Reichhardt 